\title{
Two Cases of Adult Varicella Accompanied by Hepatic Dysfunction
}

\author{
Haruo MURAOKA ${ }^{122}$, Shigeru TOKESHI ${ }^{1}$, Hirohiko $\mathrm{ABE}^{1)}$, \\ Yoichi MIYAHARA ${ }^{2)}$, Yasuyo UCHIMURA ${ }^{3)}$, Seiji NOGUCHI ${ }^{3)}$, \\ Michio SATA $^{3)}$ and Kyuichi TANIKAWA ${ }^{3)}$ \\ ${ }^{1)}$ Department of Medicine, Kumamoto Central Hospital \\ ${ }^{2}$ Miyahara Clinic
}

${ }^{3)}$ The Second Department of Medicine, Kurume University, School of Medicine, Kurume

(Received: May 9, 1997)

(Accepted: January 8, 1998)

Key words: varicella, hepatic dysfunction

\section{Introduction}

Varicella is a typical acute exanthematous viral infection caused by varicella-zoster virus $(\mathrm{VZV})^{1}$. In recently years, as far as hepatic dysfunction caused by viruses other than the hepatitis virus is concerned, there have been a few reports on hepatic dysfunction accompanying varicella following organ transplantation of Europe and America ${ }^{23)}$ and another report on an immunocompromized adult following treatment for Systemic lupus erythematosis (SLE) in Japan ${ }^{4}$. Nonetheless, we searched the MEDLINE and J MEDICINE listing the publications between 1986 and 1996 and found one report on healthy adults with varicella accompanied by hepatic dysfunction in Europe and America $^{5)}$ and two reports in Japan ${ }^{6,7)}$. Only Noguchi et al. dealt with the findings of liver biopsy ${ }^{6}$. We examined two healthy adults with varicella and mild-to-moderate hepatic dysfunction, and referred to the results of their liver biopsies. The present paper discusses this issue, citing some references.

\section{Cases}

Case 1. The patient was a 37-year-old man who received a leg burn in 1985 and had been drinking Shochu (Japanese spirit), 0.27 liter a day, for 10 years. He was admitted to our department with chief complaints of general malaise, fever and exanthema on April 13. Five days before admission, he had a fever of about $39^{\circ} \mathrm{C}$ and a rash appeared all over his body on April 10. There was no past history of varicella.

Physical examination showed a height of $172 \mathrm{~cm}$; weight, $63 \mathrm{~kg}$; blood pressure, $148 / 72 \mathrm{mmHg}$, and pulse rate, $80 / \mathrm{min}$. Diffuse vesicles and ulcers were found on the trunk and all extremities. In the abdominal region, the liver was palpable at two fingerbreadths above the right midclavicular line. Neither tenderness nor knock pain was confirmed.

Laboratory data on admission are shown in the Table 1. An elevated white blood cell count and atypical lymphocytes $(3 \%)$ were detected in the peripheral blood. There were mild-to-moderte increases in the levels of transaminase, $\mathrm{LDH}$ and biliary enzymes. The patient was negative for the following virus markers: $\mathrm{HBs}$ antigen, $\mathrm{HCV}$ antibody (second generation), herpes-simplex virus (HSV) and VZV antibody. Also, it was found that he had been exposed to Epstein-Barr virus (EBV)

Correspondence to: Haruo MURAOKA

Miyahara Clinic, 3679 Kubota-Machi, Saga-Gun 849-0203, Japan 
Table 1 Laboratory data on admission

\begin{tabular}{|c|c|c|c|c|c|}
\hline & Case 1 & Case 2 & & Case 1 & Case 2 \\
\hline Peripheral blood & & & Viral markers & & \\
\hline $\mathrm{WBC}\left(/ \mathrm{mm}^{3}\right)$ & 10,600 & 7,900 & $\mathrm{HBaAG}$ & $(-)$ & $(-)$ \\
\hline Neut $(\%)$ & 81 & 46 & $\mathrm{HCV}-\mathrm{Ab}(2 \mathrm{nd})$ & $(-)$ & $(-)$ \\
\hline $\operatorname{Eos}(\%)$ & 0 & 1 & IgG-anti-EB-VCA & $\times 320$ & $\times 80$ \\
\hline Lymph (\%) & 12 & 18 & EBNA & $\times 40$ & $\times 20$ \\
\hline Mono (\%) & 4 & 42 & IgM-anti-CMV & & $(-)$ \\
\hline Baso (\%) & 0 & 1 & anti-VZV (CF) & $<\times 4$ & $\times 16$ \\
\hline Atyp. lymph(\%) & 3 & 2 & anti-HCV $(\mathrm{CF})$ & $<\times 4$ & $<\times 4$ \\
\hline $\mathrm{RBC}\left(\times 10^{4} / \mathrm{mm}^{3}\right)$ & 459 & 510 & & & \\
\hline $\mathrm{Hb}(\mathrm{g} / \mathrm{dl})$ & 13.2 & 15.1 & Coagulation test & & \\
\hline $\mathrm{Ht}(\%)$ & 40.4 & 48.9 & $\mathrm{PT}(\%)$ & 94 & 68 \\
\hline $\operatorname{PLt}\left(\times 10^{4} / \mathrm{mm}^{3}\right)$ & 21.3 & 31.6 & $\operatorname{HPT}(\%)$ & 115 & 82 \\
\hline Blood chemistry & & & Urinalysis & & \\
\hline $\mathrm{Tp}(\mathrm{g} / \mathrm{dl})$ & 5.9 & 7.6 & & n.p. & n.p. \\
\hline $\operatorname{alb}(g / d l)$ & 3.1 & 4.7 & & & \\
\hline $\mathrm{TB}(\mathrm{mg} / \mathrm{dl})$ & 0.8 & 0.8 & & & \\
\hline $\mathrm{GOT}(\mathrm{IU} / l)$ & 113 & 57 & & & \\
\hline $\mathrm{GPT}(\mathrm{IU} / l)$ & 132 & 193 & & & \\
\hline $\mathrm{LDH}(\mathrm{IU} / l)$ & 805 & 396 & & & \\
\hline $\mathrm{AL}-\mathrm{P}(\mathrm{IU} / l)$ & 121 & 225 & & & \\
\hline$\gamma-\mathrm{GTP}(\mathrm{IU} / l)$ & 159 & 52 & & & \\
\hline LAP (G.R.-U) & 429 & 266 & & & \\
\hline
\end{tabular}

n.p.: nothing in particular, CF : complement-fixation test, EBNA: Epstein-Barr virus-assoclated nuclear antigen

in the past. Furthermore, the patient was negative for HCV antibody on September 8, five months after the onset of hepatic dysfunction. A chest X-ray taken on admission did not show any abnormalities.

Case 2. The patient was a 26-year-old man who had been drinking three bottles of beer a day for 10 years. He was admitted to the Department of Dermatology with chief complaint of fever and rash on October 30,1995 . On October 29 , he had a fever of $39^{\circ} \mathrm{C}$, and a rash and vesicles appeared all over the body the next day. After hospitalization, $780 \mathrm{mg}$ of acyclovir per day was administered from October 30 to November 6 based on the diagnosis of varicella. On November 8 , the 11 th day from the onset, the levels of sGOT and sGPT suggested hepatic dysfunction (64 and 194 IU/1, respectively). Consequently, for the purpose of close examination, he was transferred to our department on November 10, the 13th day from the onset. There was no past history of varicella.

Physical examination showed a height of $167 \mathrm{~cm}$; weight, $63 \mathrm{~kg}$; blood pressure, 140/70 $\mathrm{mmHg}$ and pulse rate $70 / \mathrm{min}$. Incrustation was detected on the trunk. In the abdominal region, the liver was palpable at one fingerbreadth above the right midclavicular line and two fingerbreadths in the epigastrium. The liver was elastic firm. Neither tenderness nor knock pain was detected.

Laboratory data on admission revealed that the levels of transaminase and biliary enzymes were increased slightly (Table 1). Increases in white blood cell count and eosinophil count were not found and atypical lymphocytes (2\%) were detected in the peripheral blood. As for changes in the coagulation system, prothrombin time (PT) and hepaplastin test (HPT) were slightly decreased. The patient was negative for virus markers such as $\mathrm{HBs}$ antigen, $\mathrm{HCV}$ antibody (second generation), and cytomegalovirus. It was found that the patient had been exposed to EBV in the past, and he was positive for VZV antibody but negative for HSV by the complement-fixation test (CF). The rssult of 
Fig. 1 Clinical course of Case 1.

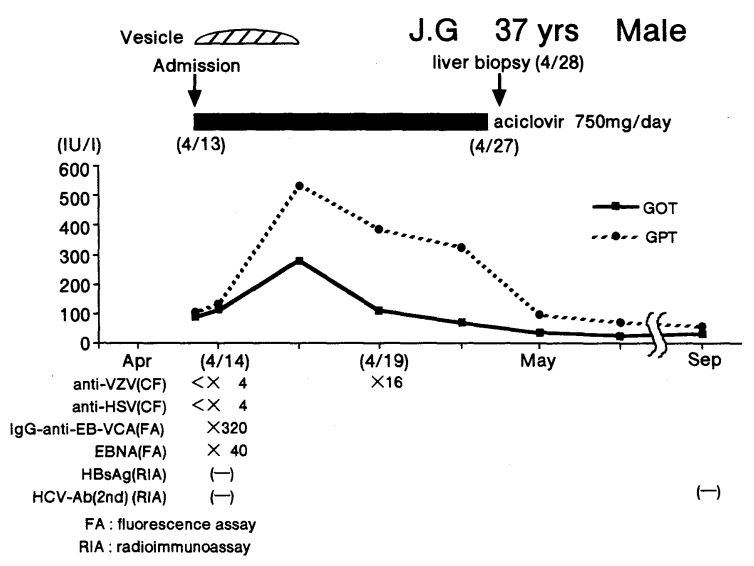

Fig. 2 Clinical course of Case 2 .

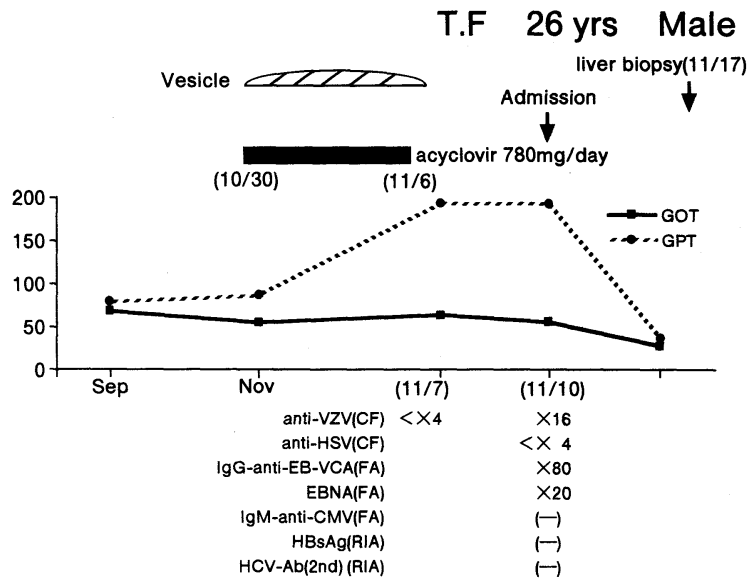

the chest C-ray taken on admission was normal.

Clinical course (Fig. 1 and 2): Although in Case 1 VZV antibody was negative on admission, the patient was diagnosed as having varicella based on clinical symptoms, and administration of $750 \mathrm{mg}$ of acylovir per day started on April 13, the 6th day from the onset. In Case 1, the levels of sGOT and sGPT were increased to 285 and 539 IU/1, respectively, on April 17, the 10th day from the onset. At this time, an increase in the eosinophil count, dermal pruritus and a rash were not detected. Even though acyclovir was administered until April 21, the level of transaminase started to decrease before this date. Then, the levels of sGOT and sGPT became normal (both $29 \mathrm{IU} / 1$ ) on May 8, the 31st day from the onset. Also, in Case 2, the levels of sGOT and sGPT had decreased to 28 and $31 \mathrm{IU} / 1$, respectively, on November 15, the 18th day from the onset. The Case 1 patient was found to be positive for VZV antibody by CF on April 19. To determine the cause of hepatic dysfunction, liver biopsies were performed in both patients on April 28, the 21st day from the onset, and on November 17 , the 20th day from the onset.

Liver biopsy (Fig. 3 and 4): In both cases, focal necrosis and neutrophil infiltration were noted in the center of the lobe, suggesting mild acute hepatitis. Also mild celluar infiltrations, consisting mainly of neutrophils, were also detected in the portal area. Neither internuclear inclusions nor coagulative necrosis, which are typical of $\mathrm{VZV}$ and $\mathrm{HSV}^{2)}$ were found. There was slight proliferation of Kupffer cells in Case 2.

\section{Discussion}

When people are first exposed to VZV, they experience varicella as a rash. VZV establishes latent infections in the sensory ganglions during the onset of the rash. In adult patients over the age of 40 and those whose immune system is compromised, VZV in the sensory ganglions is reactivated and induces herpes zoster ${ }^{1}$. Reye's syndrome ${ }^{8)}$ is known to be one of the complications of varicella in children. Pneumonitis ${ }^{5}$ is known as one of the complications of varicella in adults, and can cause death in patients suffering from varicella. Schleussing et al. ${ }^{9)}$ first reported varicella accompanied by hepatic dysfunction in 1927, and since then there have been several been several reports on hepatic dysfunction among children ${ }^{8)}$ and immunocompromized adults following transplantation ${ }^{23)}$. Nonetheless, to the best of our knowledge, there have been only four reported cases of adult varicella patients with hepatic dysfunction who had not undergone organ transplantation ${ }^{4) \sim 7}$. One of these patients ${ }^{4)}$ 
Fig. 3 Histology of liver biopsy specimen (Case 1, on the 21st day from onset). In the portal area, mild inflammatory cell infiltrationis seen. Focal necrosis is also seen. Inflammtory cells are composed mainly of neutrophils. (H \& E stain $\times 200$ ).

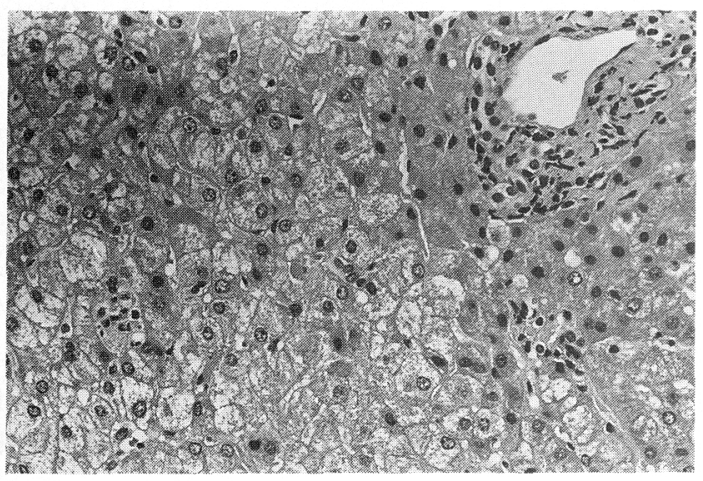

Fig. 4 Histology of liver biopsy specimen (Case 2, on the 20th day from onset). Mild focal necrosis and inflammatory cell infiltration are seen in sinusoids. Inflammatory cells are composed mainly of neutrophils. There is no findings of fatty liver. (H \& E stain $\times 200)$

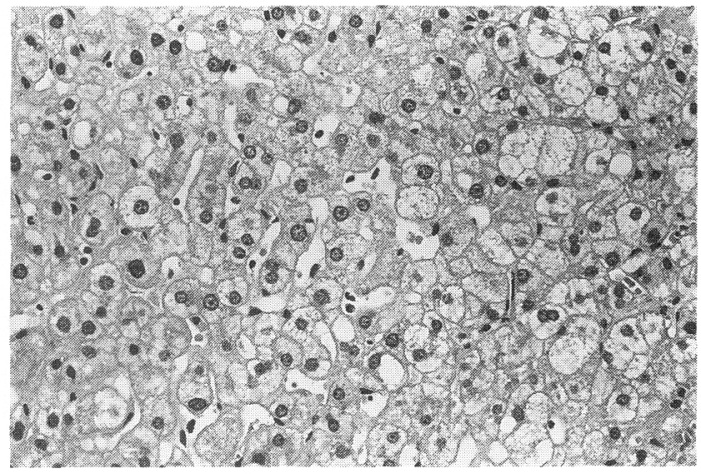

was diagnosed having as SLE and received more than $15 \mathrm{mg}$ of predonisolone per day for about six months. When this patient had a varicella-induced rash, $20 \mathrm{mg}$ of the drug per day was administered, so the immune system of this patient was believed to be compromised. Therefore, only three otherwise healthy adults have had varicella accompanied by hepatic dysfunction ${ }^{5,7)}$. However, Kobayashi $e t a l .^{7)}$ reported that, of 79 adult patients with varicella, hepatic dysfunction was confirmed in 59 patients $(71 \%)$ who did not have an underlying disease or receive drugs that might cause the dysfunction, suggesting that the rate of healthy adults with varicella accompanied by hepatic dysfunction is not low. We examined two otherwise healthy patients with varicella accompanied by mild-to-moderate hepatic dysfunction who not have pneumonitis, and live biopsies were performed on these patients.

There was no family history of liver diseases in either of the two patients in the present study, and they were negative for both HBs antigen (RIA; Dainabot Co., Ltd., Tokyo, Japan) and HCV antibody (Ortho HCV-RIA II, Ortho Diagnostic System Inc, Raritan, New Jersey, USA). Also, it was found that they had not been exposed to EBV or cytomegalovirus recently. Although the two patients regularly drank alcohol, the results of their liver biopsies did not show conditions associated with alcoholic hepatitis, such as ballooning of hepatocytes, Mallory body ${ }^{10)}$ and perihepatocytic fibrosis. Also, based on their medical history, it was determined that the they did not have alcoholic hepatitis. Only acyclovir was administered to these patients. Therefore, we deny the posibility that the hepatic dysfunction was caused by acyclovir. In Case 1, an increase in eosinophil, and the onset of the rash or dermal prupritus were not found during acylovir administration. Also, in Case 2, even thought the level of transaminase peaked at the completion of acyclovir administration, increases in white blood cell count and eosinophils were not deteced in the peripheral blood when the patient was transferred to our department. Furthermore, in both of these patients, the liver biopsy did not show the eosinophil infiltration ${ }^{11}$ that is seen in patients with drug-induced hepatic dysfunction. Baded on these findigns, it was concluded that acyclovir did not cause the hepatic dysfunction. The titer of HSV antibody determined by $\mathrm{CF}$ did not increase during the follow-up observation period in either patient; therefore, it was thought that the hepatic dysfunction experienced by the two patients was associated with VZV infection from the characteristic clinical symptoms and the increase in the titer of VZV antibody deteced by $\mathrm{CF}$. 
Patti et $a l^{3)}$ studied hepatic dysfunction in children and adult suffering from varicella between 1975 and 1988, and reported that when the immune system was compromised, the mortality rate was high in both children and adults, nonetheless, when the immune system was not compromised, varicella was asymptomatic. This finding suggested that varicella might cause hepatic fysfunction in healthy adults whose immune system was not compromised. In the present study, the chest X-ray taken on admission showed that the two patients did not suffer from pneumonitis and their immune system was not compromised.

In the present cases, the maximum level of sGOT was 285 and $64 \mathrm{IU} / 1$ (average 174.5 IU/1) in Cases 1 and 2, and the maximum level of sGPT was 539 and 194 IU/1 (average 366.5 IU/1), respectively. Thus, the levels of the two transaminases showed mild-to-moderate abnormalities. Also, Kobayashi et $a l .^{7)}$ reported that the maximum levels of sGOT and sGPT were 93 and $162 \mathrm{IU} / 1$, respectively, in 56 adult varicella patients with hepatic dysfunction, and that the level of sGPT exceeded 100 IU/ 1 in three of the 56 patients (5.8\%). Furthermore, Schlossberg et al. ${ }^{5}$ found that the level of sGOT was mildly or moderately increased in three of six adult varicella patients whose disease was complicated by pneumonia. The results of the present study also showed mild or moderate increases in the level of two transaminases.

In the present cases, the level of LDH was increased moderately to $805 \mathrm{IU} / 1$ in one patient. Kobayashi et al. ${ }^{7)}$ found that the maximum level of the $\mathrm{LDH}$ in the 56 adult varicella patients with hepatic dysfunction was $522 \mathrm{U} / 1$, and that the level of $\mathrm{LDH}$ exceeded $350 \mathrm{IU} / 1$ nine of the 56 patients (16.1\%). Schlossberg et al. $\left.{ }^{5}\right)$ reported that the level of LDH was mildly or moderately increased in five of six adult varicella patients. Therefore, their findings were in agreement with ours.

Kobayashi et al. ${ }^{7)}$ reported that the level of sGPT normalized within 18 days from the onset in the nine adult varicella patients. The number of days that is required for sGPT to normalize has not been determined. Also, Noguchi et al. $\left.{ }^{6}\right)$ stated that the change in transaminase levels was monopeaked and was not prolonged in two adult patients who developed liver injury after varicella and herpes zoster. These findings suggested that hepatic dysfunction accompanied by varicella takes a favorable clinical course in adults who do not have pneumonitis or in those whose immune system is not compromised. The level of sGPT in the two patients in the present study normalized on the 31 st and the 18th day from the onset, respectively, and these data are in agreement with the results of Kobayashi's study.

Kusne et al. ${ }^{2)}$ stated that, like hepatic dysfunction caused by HSV, the histopathological findings of hepatic dysfunction accompanying varicella was coagulative necrosis caused by a mild inflammatory reaction, and that the inflammatory cellular infiltration consisted main of neutrophils. In the present study, focal necrosis and inflammatory cellular infiltration were also found in the center of the lobe, and the infiltrating cells consisted mainly of neutrophils. These findings are in agreement with the result of the study conducted by Kusne $e t a .^{2}{ }^{2}$.

At present, the mechanism of onset of hepatic dysfunction accompanying varicella is unclear. Noguchi et al. ${ }^{6}$ ) performed liver biopsies on two adult patients with hepatic dysfunction following the onset of varicella and herpes zoster to determine the subsets of infiltrating lymphocytes. They found Leu 2a (cytotoxic/suppressor) and Leu 15 (suppressor, natural killer/killer) positive cells in the hepatocyte necrotic regions. On the other hand, it is reported that VZV particles are location in hepatic tissue ${ }^{12)}$, and it is known that VZV has a cytopathic effect on human nephrocyte and fetal pulmonary blasts ${ }^{1}$. These findings show that the hepatic dysfunction which accompanies varicella might directly correlate with hepatic dysfunction caused by VZV. The results of the present study also showed that the degree of inflammatory cellular infiltration in hepatic tissue was mild and that the infiltrating cells consisted mainly of neutrophils. Thus, these findings suggest that VZV may 
directly cause hepatic dysfunction.

In studies of more cases in the future, it will be important to investigate the clinical characteristics and histopathological findings of patients with varicella accompanied by hepatic dysfunction.

\section{References}

1) Arvin AM: Varicella-Zoster Virus. In: Fields BN \& Knipe DM, ed. Fields Virology. Vol. 2 Raven Press, New York. 1995; 2545-2586.

2) Kusne S, Pappor O, Manez R et al.: Varicella-Zoster virus hepatitis and suggested management plan for preventation of VZV in adult liver transplant recipients. Transplantation 1995; 60: 619-621.

3) Patti ME, Selvaggi KJ \& Kroboth FJ: Varicella hepatitis in the immunocompromized adult: A case report and review of the literature. Am J Med 1990; 88: 77-80.

4) Shimamura R, Dohmen K, Tsuda $\mathrm{H}$ et al:: Three cases with hepatic dysfunction accompanied by Syphilis precox, Tsutsugamushi disease and Varicella, Respectively. Rinsyo to Kenkyu 1989; 66: 3561-3563.

5) Schlossberg D \& Littman M: Varicella pneumonia. Arch Intern Med 1988; 148: 1630-1634.

6) Noguchi S, Kanda K, Sato D et al:: Two patients wih hepatic dysfunction following varicella-zoster virus infection. Jpn J Gastroentero 1988; 85(Supple): 1010.

7) Kobayashi H, Nemoto K, Imoto T et al:: Liver Involvement in Adults with Varicella. Skin Research 1990; 32: 727-731.

8) Landy SE: Varicella hepatitis and Reye's syndrome: An interrelationship? Pediatrics 1977; 60: 746-748.

9) Johnson NH: Viscerall lesion associated with varicella. Arch Pathol 1940; 30: 292-307.

10) Takada A, Matsuda $Y$, Takase $S$ et al:: A national surveillance study on alcoholic liver disease in Japan (1986-1991). Jpn J Gastroenetrol 1994; 91: 887-898.

11) Umakoshi J, Matsumoto T, SM Fazle Akbar et al.: A clinical-pathological analysis of drug induced hepatitis. -Our experience of last 5 years-. Acta Hopatol Jpn 1994; 37: 368-373.

12) Ross J, Faning WL, Beautyman et al.: Fatal massive necrosis from Varicella-Zoster hepatitis. Am J Gastroenterol 1980; 74: 423-427.

\section{水痘に合併した肝障害の 2 例}

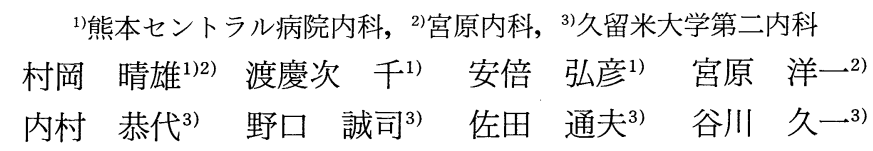

\section{要旨}

肝機能異常を伴った成人水痘の 2 例を経験し た. sGOT, sGPT 值, 及び LDH 值は共に一過性 の軽度から中等度の上昇を認めた。 sGPT 值は 2
例共に発症後 8 週間以内に正常化した回復期の肝 生検組織像では小葉中心部の focal necrosis と好 中球を主体とした炎症細胞浸潤を認め，軽い急性 肝炎の所見を呈していた。 